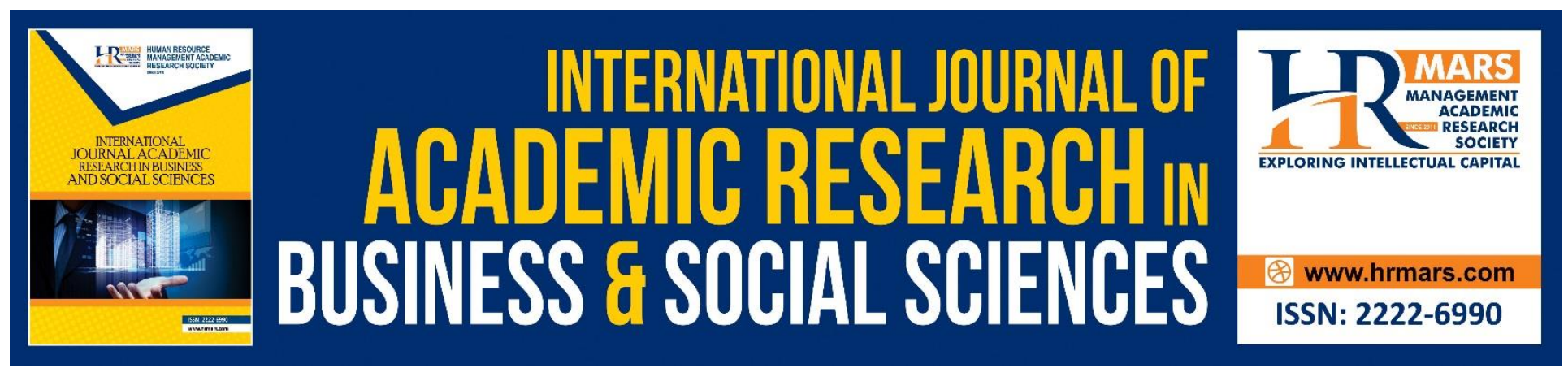

\title{
Assessing Visitors' Leisure Time and Constraints to Tourism Resort Utilization in Calabar, Cross River State, Nigeria
}

\author{
Eja, Eja I., Ojong-Ejoh Mary \& Eteng, Edet Emmanuel
}

To Link this Article: http://dx.doi.org/10.6007/IJARBSS/v9-i3/5649

DOI: $\quad 10.6007 /$ IJARBSS/v9-i3/5649

Received: 27 Jan 2019, Revised: 25 Feb 2019, Accepted: 03 March 2019

Published Online: 21 March 2019

In-Text Citation: (Eja, Mary, \& Eteng, 2019)

To Cite this Article: Eja, E. I., Mary, O.-E., \& Eteng, E. E. (2019). Assessing Visitors' Leisure Time and Constraints to Tourism Resort Utilization in Calabar, Cross River State, Nigeria. International Journal of Academic Research in Business and Socal Sciences, 9(3), 210-221.

\section{Copyright: (C) 2019 The Author(s)}

Published by Human Resource Management Academic Research Society (www.hrmars.com)

This article is published under the Creative Commons Attribution (CC BY 4.0) license. Anyone may reproduce, distribute, translate and create derivative works of this article (for both commercial and non-commercial purposes), subject to full attribution to the original publication and authors. The full terms of this license may be seen

at: $\underline{\text { http://creativecommons.org/licences/by/4.0/legalcode }}$

Vol. 9, No. 3, 2019, Pg. 196 - 207

http://hrmars.com/index.php/pages/detail/IJARBSS

JOURNAL HOMEPAGE

Full Terms \& Conditions of access and use can be found at http://hrmars.com/index.php/pages/detail/publication-ethics 


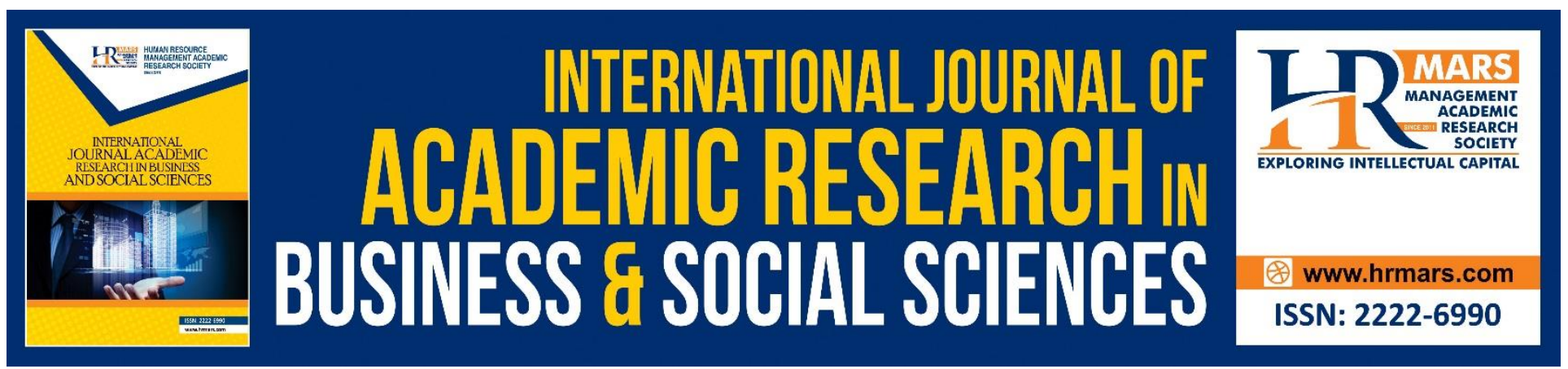

\title{
Assessing Visitors' Leisure Time and Constraints to Tourism Resort Utilization in Calabar, Cross River State, Nigeria
}

\author{
${ }^{1}$ Eja, Eja I., ${ }^{2}$ Ojong-Ejoh Mary \& ${ }^{1}$ Eteng, Edet Emmanuel \\ ${ }^{1}$ Department of Tourism Studies University of Calabar, Nigeria \\ Email: ejaiwara43@gmail.com \\ ${ }^{2}$ Department of Sociology, University of Calabar, Nigeria
}

\begin{abstract}
The rate of visitors' inflow in Calabar especially during tourism events has necessitated tourism resort development in Calabar. This paper assesses the visitor leisure time and constraints to tourism resort utilization. Seven hundred and forty-eight copies of questionnaire were distributed to visitors in the various tourism resorts. The questionnaire and checklist were the methods used in data collection. One hypothesis was stated which try to examine whether or not the utilization of tourism resorts is depended on the amount of leisure available to visitors in the area The stated hypothesis was tested using chi-square. The research findings show that several facilities that are utilized by visitors exist in the various tourism resorts. It was noticed that majority of the visitors allocated for themselves one to three hours as their leisure time in the resort. The data obtained shows that evenings were the major daily visiting time that visitors allocate for visiting the tourism resorts. The data collected shows that low patronage and high taxation were the major constraints faced by management of the tourism resorts, while obsolete facilities and poor maintenance of facilities were the observed visitors' constraints in various resorts in the area. However, effective measures must be put in place by the stakeholders that are involved in the management of the resorts so as to ensure adequate utilization of the tourism resorts in the area.
\end{abstract}

Keywords: Assessing, Leisure, Time, Tourism, Visitors

\section{INTRODUCTION}

Tourism development has become a more complex phenomenon whose social, cultural and economic implications are becoming the main engine of local economy development at all levels (Seetanah, et al., 2011). Tourism resort is a component of regional touristic product which consists of fundamental tourism support services and facilities which include resorts, accommodation, transportation and retail networks which enhances smooth operation of business activities and also 
serves as service delivery to tourists and visitors in a destination (Panasiuk, 2007). According to Innskeep (1991) in his own analysis of tourism resorts states that the tourism resource base of a country is a potential determinant of the attractiveness of a tourism destination. He further stresses that most tourism resorts provide essential facilities such as restaurants, accommodation and other utility like water and power supply which are utilized and enable visitors to stay longer in a destination. Tourism resorts operate effectively in a given destination with the availability of other tourism infrastructure such as communication, transportation among others, which encourage visitors' arrivals and at the same time create investment opportunities in the area (Saayman, 2004). In Nigeria, the establishment of the Nigerian Tourism Development Corporation (NTDC) necessitated towards the rapid growth of tourism resorts which provided great opportunities in Nigeria and in most states of the federation (Ukene, 2004). The development, rehabilitation and introduction of festival Calabar has encouraged the emergence of tourism resorts which cater and provide essential services to visitors and other fun-seekers (Eja, 2012). Accommodation, transportation and retail network provides services to numerous visitors as earlier cited by Panasiuk (2007), which according to him are major components of the tourist products in a given tourism destination. In Cross River State and Calabar in particular there exist tourism resorts which are often utilized by visitors and residents in the area.

The existence of tourism resorts in Calabar is one thing, their level of utilization is another. This is because vast tourism resorts in Cross River State lie under-utilized and are seriously degrading due to poor utilization (Aniah and Eja, 2009). Accordingly, Eja and Ajake (2012), in assessing the tourism resorts utilization in Calabar, affirmed that resorts play a fundamental role in the destination development and its effective utilization depends on the inflow of visitors into the state. They further stressed that most resorts provide certain facilities that provide comfort to numerous visitors during their stay in the area.

In Cross River State and Calabar in particular, the introduction of the Calabar Carnival and the development of the existing tourism potentials have greatly influenced the rate of visitors' inflow to the existing tourism resorts, hence giving rise to the development of tourism resorts by both the public and private sector to cater for the needs of various visitors while they stay in Calabar.

However, despite the huge capital investment in the provision of tourism resorts and other recreational facilities by the government and private sector in Calabar, there is still low level of utilization of these great resources by the public. In most cases, the existing ones are undergoing the rise and fall in their operations. Apart from this, the establishment of the Carnival Calabar seem to be the only catalyst that has effectively encouraged tourism resorts utilization in Calabar. It is on this note that one would ask if there is no leisure time created by the government for staff, what are the constraints that are responsible for the low utilization and development of tourism resorts in Calabar which is the basis of this research work, to assess visitors' leisure time and constraints to utilization and development of tourism resorts in Calabar.

\section{Literature Review}

Tourism is often welcomed as an industry being desperately needed for foreign exchange, employment and a 'modern way of life. To others it raises the spectra of destruction of traditional lifestyles, neo-colonialist relationship of exploitation, over dependence upon an unreliable, single 
industry and inflation. It is further concluded that in spite of these cases, tourism will only flourish given appropriate conditions. Tourism like any other industry, requires sophisticated planning and organization if its full potential is to be realized. Tourism in Cross River State is not devoid of problems that inhibit its development.

The problem of sustainable tourism is that developing countries are competing for tourists without developing the needed infrastructure nor linkages to host communities (Osamwonyi, 2004). In most countries of the world with great tourism potentials visitors and tourists want to have clean water, secured good accommodation, and excellent facilities which would help guarantee their comfort in any destination. To develop tourism some countries, advocate for the need to build and upgrade facilities such as hotels, retail shops, restaurants, medical facilities, golf courses, stadia, resorts and publish guides for recreation activities (Eja 2013)

In most tourism destination security is considered one among other problems confronting resorts development. Places such as Ekajuk in Ogoja, Boje and Isom-Bendege in Boki Local Government in Cross River State, the incessant clashes among communities have affected the rate of tourism resorts utilization in the area. The development of tourism resorts in Nigeria cities such as Akwa Ibom, Rivers, Jos Plateau among others is characterized by many challenges which have affected the rate of resorts utilization in the area (Uya,2004). In his argument reported that the tourist industry is still dogged by inconsistent government policies and inadequate implementation of such policy to drive the industry and ensure that the existing tourism industry are effectively utilized. The inadequate training of manpower, lack of effective funding and the organization of tourism programme have advocated for the provision and supply of the needed infrastructure for the utilization visitors (Ayodele, 2002). This assertion was affirmed by Ukene (2004) which according to him poor road network and lack of social amenities such as electricity, pipe borne water in tourism resorts have discourage visitors towards effective utilization of the resort in Cross River State and Calabar in particular. The problem of resort utilization by visitors in most developing countries is lack of sufficient infrastructures to link visitors to where these tourism resorts are located. Visitors wishes to spend their leisure times in any resorts would preferred destinations where the resorts have adequate social amenities such as clean water, effective security network and good accommodation (Osamwonyu, 2004). In Nigerian states, the poor utilization of most of the existing tourism resorts is due to lack of trained employees and that the government do not make provision for staff and other employees to engage in holidays as majority of them are always found in their homes without any recreational engagement (Okon,2006) He further stress that qualified employees are needed in the hospitality industry, this according to him would reduce the constraints faced by visitors in the hospitality industry.

In Cross River State, majority of the employees in the various industries do not create time for leisure activities rather they spend time in their domestic activities. Apart from this, those who engage in recreational activities in most cases spend little time in utilizing the tourism resort due to lack of finances and in some time, the services render by the hospitality industry seem to be very poor hence discourage more visitors to utilize the resorts. Furthermore, the facilities sometime provided are not of standard and in most case visitors spend so much money without obtaining the satisfaction needed while his stay in the resort. 


\section{Methodology}

The research is anchored on assessing visitors' leisure time and constraints to tourism resorts utilization. Four major tourism resorts were used for this research which include Marina Resort, Calabar Habour Resort and Aqua Vista Resort. Seven hundred and forty-eight (748) copies of questionnaire were administered to the three tourism resorts in the area. An estimated weekly average visitors' arrivals of one thousand five hundred and thirty $(1,530)$ was used as sample population for the study. A sample size of seven hundred and forty-eight (748) visitors were drawn from the sample population using the Taro Yamene formula. The questionnaires were distributed to visitors with the aid of resort staff in the respective resorts using random sampling technique. However, two hundred and forty-three (243) copies of the questionnaire were distributed to Marina resort, one hundred and seventy-eight (178) questionnaires distributed to Calabar Habour Resort and one hundred and twenty-four (124) questionnaires distributed to Aqua Vista Resort. The information captured in the questionnaire include recreational facilities provided in each tourism resort, leisure time allocation to each resort, visitors' daily visiting time, management and visitors' constraints in the resorts. The stated hypothesis was tested using chi-square $\left(x^{2}\right)$ which was used to observe the various leisure times allocated by visitors to the utilization of the various tourism resorts in the area.

\section{Findings}

\section{Leisure time allocated to the resort}

The visitor's leisure time allocated by visitors to the resorts presented in tables revealed that 53 to 35 percent of visitors in the resorts allocate 3 to 4 hours as their leisure time to visit the resorts, while 12 percent have no fixed hours of visit to the resorts. Table 1 shows that Marina resort and orange resort were the resorts that visitors allocated more leisure time as observed with over 112 and 110 visitors followed by Calabar resort with a value of 95 visitors. It was noticed that Calabar harbor resort recorded a respondents' value of 95 visitors. It was also noticed that Calabar harbor resort had more visitors who do not have allocate fixed time to themselves as observed with 40 visitors followed by Aqua vista with 23 visitors.

Table 1: Leisure time allocated by visitors to the resorts

\begin{tabular}{lllllll}
\hline Leisure time & Marina & $\begin{array}{l}\text { Calabar } \\
\text { resort }\end{array}$ & $\begin{array}{l}\text { Resort } \\
\text { harbor } \\
\text { resort }\end{array}$ & $\begin{array}{l}\text { Orange } \\
\text { Resort }\end{array}$ & $\begin{array}{l}\text { Aqua vista } \\
\text { resort }\end{array}$ & \\
\hline 1-3 hours & 112 & 95 & 110 & 81 & 398 & 53 \\
3-4 hours & 120 & 43 & 76 & 20 & 259 & 35 \\
Not fixed & 11 & 40 & 17 & 23 & 91 & 12 \\
Total & 243 & 178 & 203 & 124 & 748 & 100 \\
\hline
\end{tabular}

Source: Field survey (2018)

The result from the tested hypotheses presented in t a b le $2 \mathrm{~s} \mathrm{how} \mathrm{s}$ a calculated value of $X^{2} 196.085$ greater than critical $X^{2}$ value of 12.59 . The result revealed that $X^{2}$-calculated value is greater than $X^{2}$-critical indicating positive dependence. Thus, rejecting the null $\left(H_{0}\right)$ hypothesis and 
INTERNATIONAL JOURNAL OF ACADEMIC RESEARCH IN BUSINESS AND SOCIAL SCIENCES

Vol. 9, No. 3, March, 2019, E-ISSN: 222 2-6990 ¿ 2019 HRMARS

accepting the alternative hypothesis $\left(\mathrm{H}_{1}\right)$ which stated that the utilization of the tourism resorts is dependent on the amount of leisure time available to visitors in the area. This hypothesis was tested using data on table 2 .

Table 2: Summary of chi-square analysis on the visitors' leisure time allocated to the resorts

\begin{tabular}{llllllll}
\hline $\begin{array}{l}\text { Visitors' } \\
\text { leisure } \\
\text { time }\end{array}$ & $\begin{array}{l}\text { Marina } \\
\text { resort }\end{array}$ & $\begin{array}{l}\text { Utilization of tourism resorts } \\
\text { Calabar } \\
\text { harbor }\end{array}$ & $\begin{array}{l}\text { Orange } \\
\text { resort }\end{array}$ & $\begin{array}{l}\text { Aqua vista } \\
\text { resort }\end{array}$ & $\begin{array}{l}\text { Column } \\
\text { resortal }\end{array}$ & Cal. $x^{2}$ & df Crit. $x^{2}$ \\
\hline $1-3$ hours & 112 & 95 & 110 & 81 & 398 & & \\
3-4 hours & 120 & 43 & 76 & 20 & 259 & 196.085 & 612 \\
Not fixed & 11 & 40 & 17 & 23 & 91 & & \\
Total & 243 & 178 & 203 & 124 & 748 & & \\
\hline
\end{tabular}

Source: Field survey (2018)

\section{Visitors Daily Visiting Time}

The visitors' daily time spent in the tourism resort presented in Fig. 1 indicated that visitors spend more of their daily time in the evening and afternoon in the resorts as observed with values of 60 and 28 percent while 2 percent of visitor have no specific daily visiting time to the resort. It was also noticed in Fig. 2 that Marina resort and Orange resort have more visitors that visit the resorts in the evening as indicated with values of 140 and 130 visitors compared to Calabar harbor resort and Aqua vista with values of 123 and 55 visitors.

Fig. 1: Visitors' daily visitor time

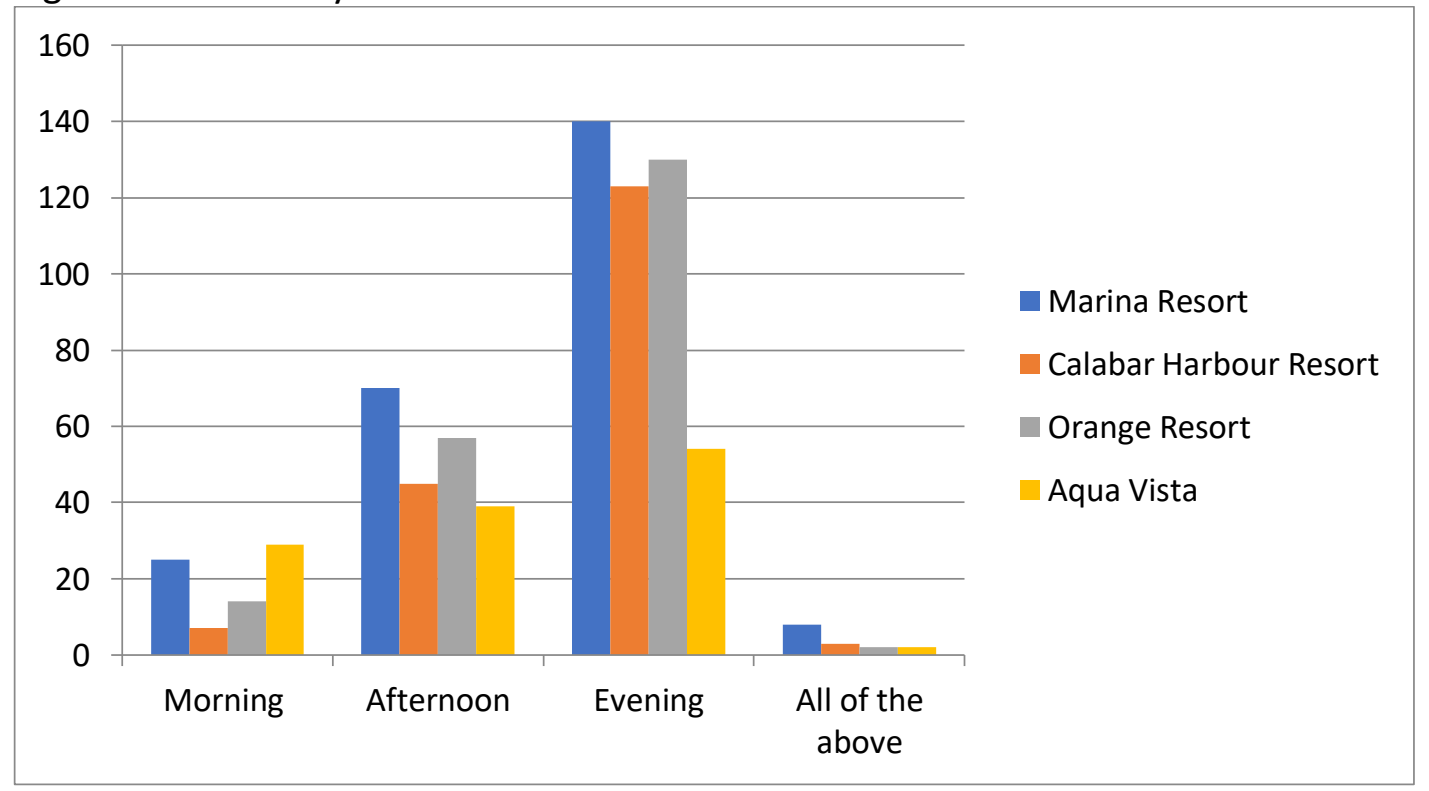

Source: Field survey (2018) 


\section{Management Constraints in the Tourism Resorts Development}

The management constraints in the development of tourism resorts presented in Table 3 revealed that low patronage was the major management constraints in the development of tourism resort as observed with a high value of 32.0 percent and 24 percent. It was also noted that lack of tourism related activities all year round was a management constraint to tourism resort development with a value of 16 percent. Furthermore, the data obtained in table 3 revealed that seasonality in the operation of the tourism resorts and poor government commitment in tourism were also management constraints towards tourism resort development as observed with values of 12 percent and 8 percent respectively. This result shows that government policy in tourism development in the state do not encourage growth in operations of tourism resorts in the area. Besides, the poor attitude of recreationists was another constraint to tourism resort development as noticed in Table 3 with a value of 7 percent.

Table 3: Management constraints in the tourism resorts development

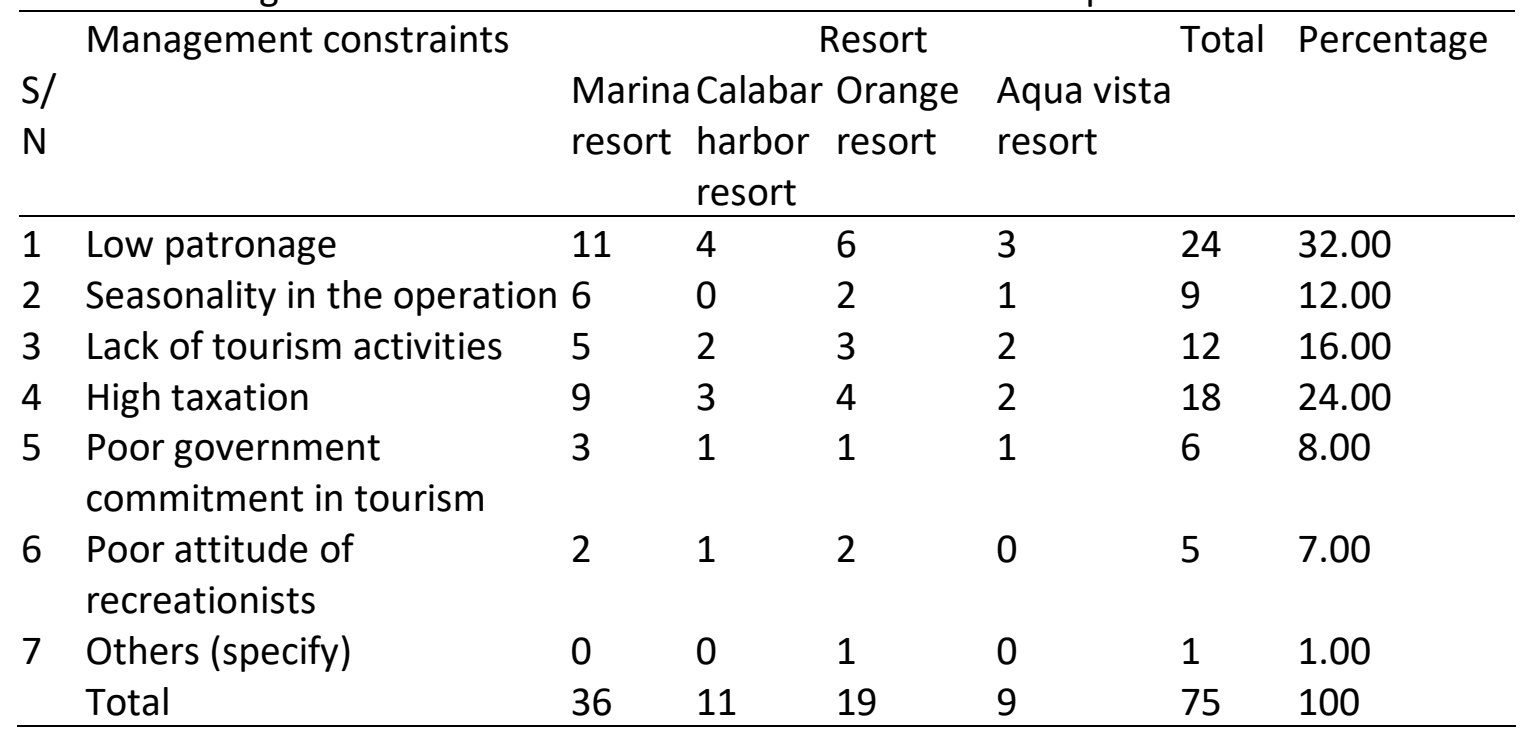

Source: Field survey (2018)

\section{Visitors' Constraints in Resort Utilization}

The observed visitors constraints in the tourism resorts presented in figure 2 indicates that obsolete facilities, poor maintenance, inadequate facilities and congestion were the major visitors' constraints with total values of 204, 151, 138 and 130 represented by 27, 20, 19 and 17 percent respectively. The figure further revealed that though facilities were not adequate to cater for the need of the visitors in the resorts, visitors also complained of poor maintenance, obsolete facilities and congestion.

However, figure 2 revealed that despite the huge patronage enjoyed by the two resorts viz, Marina Resort and Orange Resort in the area, visitors still face challenges in those resorts, represented with values of 243 and 203 respectively. 
INTERNATIONAL JOURNAL OF ACADEMIC RESEARCH IN BUSINESS AND SOCIAL SCIENCES

Vol. 9, No. 3, March, 2019, E-ISSN: 2222-6990 @ 2019 HRMARS

Fig. 2: Visitors constraints in tourism utilization

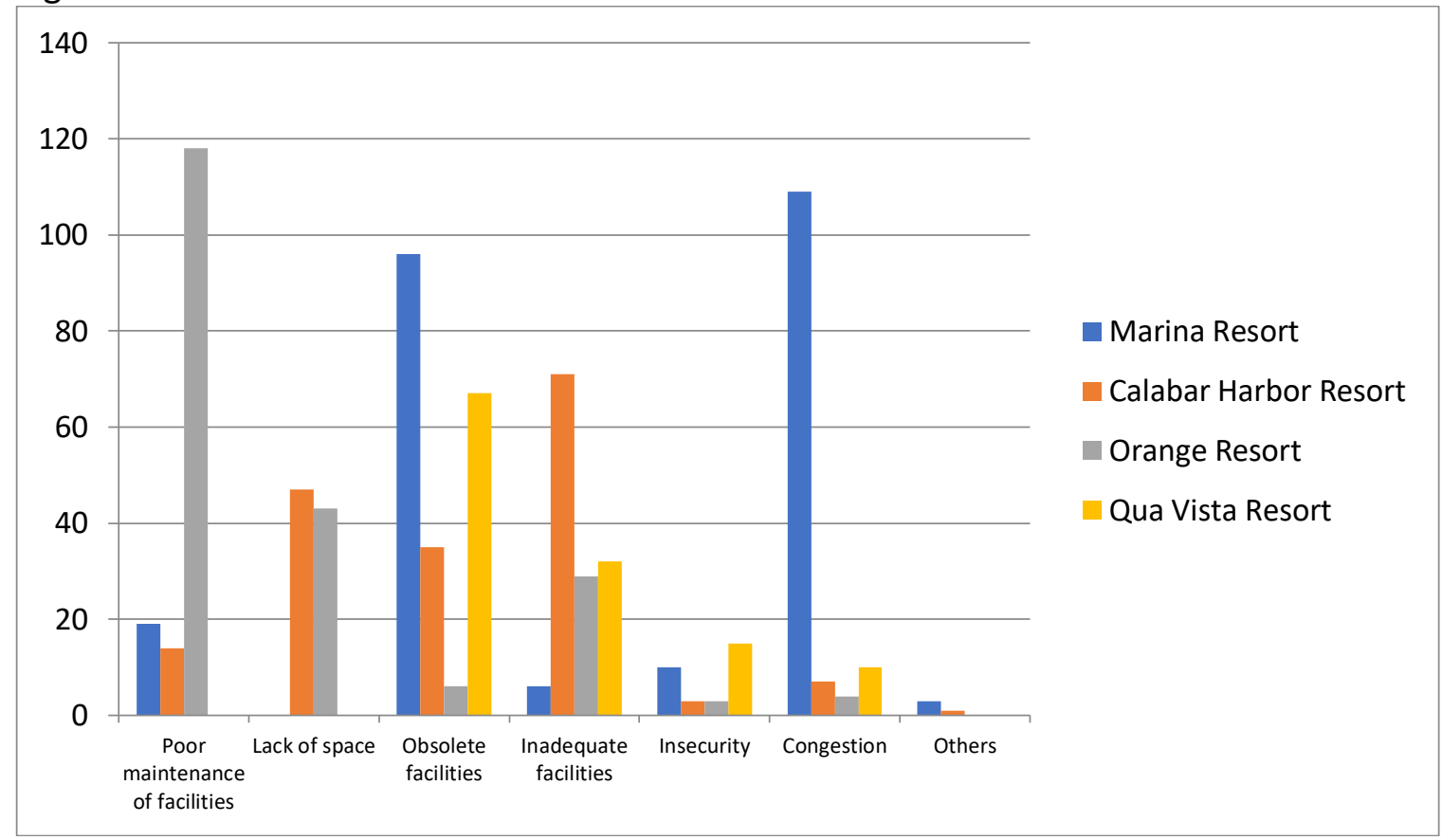

Source: Field survey (2018)

\section{Recreational Facilities and Services Provided in the Resorts}

The recreational facilities and services provided in the various recreational resorts presented in Table 4 indicate that cocktail bar and bar sport facilities were the major recreational facilities that are provided by the tourism resorts with values of 34.2 percent and 13.5 percent, followed by garage and parking space with value of 12.8 percent. The data obtained in the field also shows that restaurants and banquet facilities were also recreational facilities that were provided in the various resorts with values of 10.4 percent and 8.1 percent respectively.

Table 4 also revealed that out of 748 respondents who responded on facilities and services provided in the Aqua vista resorts, Marina Resort, Calabar Harbour Resort and Orange Resort. It was noticed in Table 4 that Marina Resort an Orange Resort were seen as resorts with highest facilities and services provided with total values of 243 and 203 respectively. Conversely, Calabar harbor and Aqua Vista resorts are viewed to have less and inadequate facilities. 
Table 4: $\quad$ Recreational facilities and services provided in the resorts

\begin{tabular}{|c|c|c|c|c|c|c|c|}
\hline S/ & Recreational Facilities and & & & Resort & & Total & Percentage \\
\hline $\mathrm{N}$ & services & $\begin{array}{l}\text { Marin } \\
\text { resort }\end{array}$ & $\begin{array}{c}\text { a Calabar } \\
\text { harbor } \\
\text { resort }\end{array}$ & $\begin{array}{l}\text { Orange } \\
\text { resort }\end{array}$ & $\begin{array}{l}\text { Aqua vista } \\
\text { Resort }\end{array}$ & & \\
\hline 1 & Cocktail bar & 123 & 68 & 42 & 23 & 256 & 34.2 \\
\hline 2 & Banqueting facilities & 1 & 32 & 28 & 0 & 51 & 8.1 \\
\hline 3 & Valet & 0 & 4 & 20 & 0 & 24 & 3.2 \\
\hline 4 & Sport facilities & 43 & 0 & 26 & 32 & 101 & 13.5 \\
\hline 5 & Garaging/parking space & 4 & 46 & 31 & 15 & 96 & 12.8 \\
\hline 6 & Cinema and entertainment & 6 & 10 & 0 & 0 & 16 & 2.1 \\
\hline 7 & Restaurant & 26 & 6 & 18 & 26 & 76 & 10.4 \\
\hline 8 & TV and video in rooms & 32 & 7 & 24 & 18 & 8 & 1.0 \\
\hline 9 & Others & 8 & 5 & 14 & 10 & 37 & 4.9 \\
\hline & Total & 243 & 178 & 203 & 124 & 748 & 100 \\
\hline
\end{tabular}

Source: Field survey (2018)

\section{Conclusion}

The development of tourism resorts in Calabar has greatly influenced visitors' inflow in the area. This research shows that tourism resorts in Calabar provide great opportunities for numerous visitors to recreate during their leisure time. It was noticed from the data collected that most facilities in each of the resorts determined the leisure daily time spent by individuals in the resorts. However, in spite of the fact that tourism resorts exist in Calabar, there exist constraints faced by both the management and visitors which affect their utilization. These constraints range from obsolete facilities, poor maintenance of available facilities, poor attitude of visitors among others. Apart from this, high taxation, lack of tourism framework to ensure tourism related activities all year round among others in the area. The presence of tourism related activities would ensure effective utilization of the tourism resorts in the area.

\section{Recommendations}

- The government should ensure that the tax regime imposed on operators of tourism resorts is reduced so as to enable efficient and effective service delivery by the management of these resorts.

- The government should provide a task force that will enforce the leisure time created to workers in the state. The task force would ensure that various categories of staff in the state engage in recreation during leisure time.

- The stakeholders in the tourism industry must provide adequate security especially where these resorts are located. This would guarantee the safety of visitors while they stay in the resort during the leisure times.

- The management of the various tourism resorts must upgrade their facilities so as to ensure 
INTERNATIONAL JOURNAL OF ACADEMIC RESEARCH IN BUSINESS AND SOCIAL SCIENCES

Vol. 9, No. 3, March, 2019, E-ISSN: 222 2-6990 @ 2019 HRMARS

adequate utilization by visitors.

- The government must ensure that effective policies are put in place in order to ensure smooth operation of the tourism resorts in the area. 
INTERNATIONAL JOURNAL OF ACADEMIC RESEARCH IN BUSINESS AND SOCIAL SCIENCES

Vol. 9, No. 3, March, 2019, E-ISSN: 222 2-6990 ¿ 2019 HRMARS

\section{References}

Aniah, E. J. and Eja, E. I. (2009). Tinapa Business Resort: “A strategy for sustainable rural livelihood in Cross River State, Nigeria" International Journal of Business Management, Vol. 4, No. 6, pp. 121-127

Eja, E. I. (2012) "Success factors determining Nigeria as a tourist destination". Journal of Emerging Trends in Education, Research and Policy Issues, 3(4): 426-432

Eja, E. I.; Ajake, A. O.; Inah, S. A. (2012)). The spatial analysis of hotel strata and rate of tourist's inflow in the hotel industry. Calabar Scenario Research on Humanities and Social Sciences, 2(5), 4452

Eja, Eja I. and Ajake, Anim O. (2012). The spatial analysis of hotel strata and rate of tourist's inflow in the hotel industry: Calabar scenario. Research on Humanities and Social Sciences, Vol. 2, No. 5, pp. 44-52

Eja, Eja I. and Eni, Imoke D. (2014) The effect of Tinapa Business Resort development on surface water quality in Cross River State, Nigeria. Academic Research International, Vol. 5, No. 6, pp. 219231

Innskeep, E. (1991). "Tourism planning: An integrate and sustainable development" Van Nostrand Reinheld, New York

Koshita, E. O. (2001). "The role of national park in the development of tourism in Nigeria", An unpublished B.Sc. project submitted to the Department of Geography, University of Calabar, 31-34

Mathieson, A. \& Wall, G. (2005). Tourism: Economic, physical and social impacts. England: Longman

Okon, U. (2006) "Tourism: An emerging industry in Cross River State", Platinum Magazine, May 20

Osamwoye, J. O. (2004). Re-engineering Nigeria tourism industry for capital market financing. The Guardian, Lagos: Guardian Publishers, June 23

Panasiuk, C. (2007). The destination product and its impact on traveler perception. Tourism Management, 21:43-52

Pearce, D. (1989). "Competitive destination analysis in Southeast Asia” Journal of Travel Research, 35(4): 166-24

Saayman, A. (2004). The determinants of tourist arrivals in Africa: A panel data regression analysis paper presented at the International Conference, Centre for the Study of African Economics, 
INTERNATIONAL JOURNAL OF ACADEMIC RESEARCH IN BUSINESS AND SOCIAL SCIENCES

Vol. 9, No. 3, March, 2019, E-ISSN: 222 2-6990 @ 2019 HRMARS

University of Oxford.

Seetenah, B., Juwaheer T. D. and Sabaha, A. U. (2011). Does infrastructure matter in tourism development? University of Mauritius Research Journal, 17: 98-108

Ukene, D. (2004). “Marketing eco-tourism in Cross River State. A paper presented during the $2^{\text {nd }}$ Cross River State Summit for the Federal Government Tourism Committee, State Library Complex, Calabar 